\title{
IMPLEMENTASI MEDIA UTANGKLEK TERHADAP PENINGKATAN HASIL BELAJAR SISWA SEKOLAH DASAR
}

\section{Frandika Fajar Juliarto, Ika Oktavianti, dan Imaniar Purbasari}

Universitas Muria Kudus

Email: FrandikaFajar70@gmail.com; ika.oktavianti@umk.ac.id; imaniar.purbasari@umk.ac.id

\section{Info Artikel}

Sejarah Artikel:

Diserahkan 15 April 2020

Direvisi 15 April 2020

Direvisi 20 Juni 2020

Disetujui 23 Juni 2020

\section{Keywords: \\ utangklek,}

ecosystem balance,

social studies and indonesian

\section{Abstract}

This study aims to describe the application of the traditional utangklek game and examine the improvement of student learning outcomes on the theme of 5 sub-themes of ecosystem balance class V SDN Widorokandang.

Classroom action research was conducted in class V SDN Widorokandang Pati with 20 students as research subjects. This research consists of two cycles and each cycle consists of 4 stages, namely planning, implementation, observation, and reflection. The independent variable in this study is utangklek media. While the dependent variable is learning outcomes. The research instrument consisted of tests, observations, interviews, and documentation. The analysis used is qualitative analysis and quantitative analysis.

The results showed there was an increase in completeness of the learning outcomes aspects of students' knowledge of social studies in the first cycle by $60 \%$ and the second cycle by $80 \%$. The completeness of learning outcomes for Indonesian content in cycle I was $65 \%$ and cycle II was $80 \%$. Learning outcomes aspects of social studies students' skills in the first cycle by $65 \%$ in good qualifications increased in the second cycle by $80 \%$ in good qualifications. The completeness of learning outcomes of Indonesian content in the aspect of skills in the first cycle by 55\% in the qualifications is good enough to $80 \%$ in the good qualifications. It proves that the application of the traditional utangklek game can improve the learning outcomes of fifth grade students at SDN Widorokandang.

\begin{abstract}
Abstrak
Penelitian ini bertujuan untuk mendeskripsikan penerapan permainan tradisional utangklek dan mengkaji peningkatan hasil belajar siswa pada tema 5 subtema keseimbangan ekosistem kelas V SDN Widorokandang.

Penelitian tindakan kelas dilaksanakan pada kelas V SDN Widorokandang Pati dengan subjek penelitian 20 siswa. Penelitian ini terdiri dari dua siklus dan setiap siklus terdiri dari 4 tahapan yaitu perencanaan, pelaksanaan, pengamatan, dan refleksi. Variabel bebas dalam penelitian ini adalah media utangklek. Sedangkan variabel terikatnya adalah hasil belajar. Instrumen penelitian terdiri dari tes, observasi, wawancara, dan dokumentasi. Analisis yang digunakan adalah analisis kualitatif dan analisis kuantitatif.

Hasil penelitian menunjukkan terdapat peningkatan ketuntasan hasil belajar aspek pengetahuan siswa muatan IPS pada siklus I sebesar $60 \%$ dan siklus II sebesar $80 \%$. Ketuntasan hasil belajar muatan Bahasa Indonesia pada siklus I sebesar 65\% dan siklus II sebesar $80 \%$. Hasil belajar aspek keterampilan siswa muatan IPS pada siklus I sebesar $65 \%$ pada kualifikasi baik meningkat pada siklus II sebesar $80 \%$ pada kualifikasi baik. Ketuntasan hasil belajar muatan Bahasa Indonesia aspek keterampilan pada siklus I sebesar $55 \%$ pada kualifikasi cukup baik menjadi $80 \%$ pada kualifikasi baik. Hal itu membuktikan bahwa penerapan permainan tradisional utangklek dapat meningkatkan hasil belajar siswa kelas V SDN Widorokandang.
\end{abstract}




\section{PENDAHULUAN}

Amanat Kurikulum 2013 adalah pembelajaran tematik terpadu dimana guru berperan sebagai fasilitator dalam proses pembelajaran. Proses pembelajaran diharapkan menarik dan dapat mengajak siswa untuk berperan aktif sehingga siswa akan mudah memahami materi yang disampaikan oleh guru. Tematik merupakan pembelajaran yang menggunakan tema-tema, di dalamnya terdapat beberapa mata pelajaran yang diharapkan memberikan pengalaman belajar yang bermakna pada siswa. Senada dengan pendapat Ardianti (2015) bahwa tematik disajikan dengan mengaitkan antar beberapa kompetensi dasar suatu mata pelajaran yang melahirkan satu atau beberapa tema pembelajaran. Pada Subtema Keseimbangan Ekosistem, peneliti memilih muatan IPS dan Bahasa Indonesia.

Berdasarkan hasil observasi yang dilakukan peneliti di SDN Widorokandang, Kecamatan Pati, Kabupaten Pati, peneliti memperoleh informasi bahwa guru masih kesulitan dalam hal menentukan media yang tepat untuk digunakan dalam membantu proses kegiatan pembelajaran sehingga guru jarang menggunakan media. Guru mendominasi kegiatan pembelajaran sehingga keaktifan siswa dalam pembelajaran rendah. Selain itu, siswa juga merasa kurang senang dan kurang tertarik dengan pembelajaran yang diajarkan guru karena model yang dipakai hampir sama setiap harinya jadi waktu pelajaran kadang siswa merasa malas untuk berpikir sehingga tidak terjadi kerjasama kelompok yang baik. Hal tersebut berdampak terhadap hasil belajar siswa yang kurang maksimal. Proses kegiatan pembelajaran yang dilaksanakan oleh guru masih terasa seperti KTSP, guru hanya mengajar berdasarkan pada buku guru yang tersedia tanpa menggunakan media pembelajaran yang inovatif, sehingga berpengaruh pada hasil belajar siswa.

Melihat dari kenyataan tersebut, maka diperlukan perbaikan dalam proses pembelajaran agar dapat meningkatkan hasil belajar siswa. Muatan mata pelajaran yang perlu ditingkatkan khususnya di SDN Widorokandang adalah muatan Ilmu Pengetahuan Sosial dan Bahasa Indonesia. Hal ini berdasarkan pada nilai yang belum memenuhi Kriteria Ketuntasan Minimal (KKM) di SDN Widorokandang yaitu 70. Dari 20 siswa, yang mampu mencapai nilai sesuai KKM Muatan IPS adalah 7 siswa atau jika di persentase hanya $35 \%$. Sedangkan pada muatan Bahasa Indonesia, dari 20 siswa yang mampu mencapai nilai sesuai KKM muatan Bahasa
Indonesia adalah 6 siswa atau jika di persentase sebanyak 30\%. Hasil observasi aspek keterampilan siswa kelas V SDN Widorokandang pada muatan IPS memperoleh persentase $45 \%$ dengan kualifikasi cukup baik, sedangkan pada muatan Bahasa Indonesia memperoleh persentase $40 \%$ dengan kualifikasi cukup baik. Alasan lainnya menurut Ismaya dan Santoso (2019) bahwa melalui pembelajaran IPS, siswa memperoleh pengetahuan, keterampilan, sikap dan kepekaan untuk menghadapi hidup dengan tantangantantangannya. Terkait dengan hal tersebut, guru harus mampu melakukan inovasi pembelajaran agar dapat meningkatkan hasil belajar siswa yang belum mencapai KKM.

Berdasarkan masalah yang ditemukan, maka peneliti memberikan solusi dengan menggunakan media pembelajaran yang akan mempermudah guru dalam melakukan pembelajaran. Menurut Sadiman, et al (2014) berpendapat bahwa media adalah segala sesuatu yang dapat digunakan untuk menyalurkan pesan dari pengirim ke penerima sehingga dapat merangsang pikiran, perasaan, perhatian, dan minat serta perhatian siswa sedemikian rupa sehingga proses pembelajaran terjadi. Sedangkan Hakim dan Haryudo (2014) mengungkapkan bahwa dalam aktivitas pembelajaran, media didefinisikan sebagai suatu alat yang dapat membawa informasi dan pengetahuan dalam interaksi yang berlangsung antara guru dengan siswa. Media yang peneliti gunakan adalah utangklek.

Utangklek merupakan media yang didesain oleh peneliti untuk suatu pembelajaran dengan menggunakan permainan tradisional berupa engklek dan permainan ular tangga. Menurut Hapidin dan Yenina (2016 bahwa permainan tradisional sendiri merupakan bentuk ekspresi dan apresiasi dari tradisi masyarakat dalam menciptakan situasi serta kegiatan yang gembira dan menyenangkan. Sedangkan Oktavianti dan Ratnasari (2017) berpendapat bahwa engklek merupakan permainan fisik tradisional dengan gerakan melompat dengan satu atau dua kaki pada petak yang digambar di tanah. Permainan engklek dapat melatih kemampuan motorik siswa. Hal tersebut sejalan dengan pendapat Mardayani, et al (2016) yang menjelaskan bahwa engklek dapat melatih kemampuan motorik kasar anak, kejujuran, kerjasama, kekompakan, ketrampilan, ketangkasan, keseimbangan, dan sikap, serta dapat melatih jiwa kesosialan anak dalam menghadapi kehidupan bermasyarakat.

Pemainan tradisional engklek dalam penelitian ini dikombinasi dengan permainan 
ular tangga sehingga siswa bermain melempar dadu, kemudian siswanya menjadi pion dan bermain ular tangga sambil engklek. Pada nomor ular tangga terdapat kartu pertanyaan atau kartu jawaban yang bersifat rahasia dan soalnya sesuai dengan apa yang telah dijelaskan guru. Apabila siswa dari salah satu kelompok berhasil menjawab pertanyaan tersebut, maka kelompoknya akan memperoleh poin skor. Sedangkan kelompok lain yang tidak bisa menjawab, maka kelompok akan diberikan hukuman sesuai dengan kesepakatan siswa. Kelompok yang ditunjuk menjawab dengan benar maka akan mendapatkan poin, jika salah maka kelompok lain diberikan kesempatan untuk menjawab. Media ini menuntut adanya peran aktif dari semua anggota kelompok. Setiap individu dalam kelompok akan berusaha memahami materi dengan sungguh-sungguh agar mendapatkan poin bagi kelompoknya. Dengan demikian, hasil belajar akan meningkat.

Penggunaan media utangklek menciptakan pembelajaran yang aktif, menyenangkan dan tentunya akan membuat siswa lebih giat belajar dengan sungguhsungguh karena ular tangga yang akan peneliti gunakan terdapat keunikan tersendiri. Hal ini diharapkan dapat meningkatkan aktivitas siswa yang berdampak pada hasil belajar siswa khususnya pada siswa kelas V SDN Widorokandang pada muatan IPS dan Bahasa Indonesia. Sjukur (2012) menyatakan bahwa hasil belajar adalah suatu kemampuan yang diperoleh individu setelah proses belajar berlangsung, yang dapat memberikan perubahan tingkah laku baik pengetahuan, pemahaman, sikap dan keterampilan siswa sehingga menjadi lebih baik dari sebelumnya. Selaras dengan pendapat Nurbaiti (2018) bahwa hasil belajar merupakan hasil yang diperoleh dari siswa setelah terjadinya proses pembelajaran yang ditunjukan dengan nilai tes yang diberikan oleh guru setiap selesai memberikan materi pelajaran pada satu pokok bahasan. Sedangkan Purwanto (dalam Mas'udah dan Aini, 2018) menyatakan bahwa hasil belajar merupakan pencapaian akhitr dari tujuan pendidikan terhadap siswa yang mengikuti proses belajar mengajar. Hasil belajar yang dikaji dalam penelitian ini meliputi hasil belajar aspek pengetahuan dan aspek keterampilan.

Tujuan penelitian ini mendeskripsikan penerapan permainan tradisional utangklek dan mengkaji peningkatan hasil belajar siswa pada tema 5 subtema keseimbangan ekosistem kelas V SDN Widorokandang.

\section{METODE PENELITIAN}

Jenis penelitian yang dilakukan yaitu Penelitian Tindakan Kelas (PTK) atau Classroom Action Research. Uno, et al (2011) PTK adalah penelitian yang dilakukan oleh guru di dalam kelasnya sendiri melalui refleksi diri, dengan tujuan untuk memperbaiki kinerjanya sebagai guru, sehingga proses pembelajaran dapat berjalan dengan baik, dan hasil belajar siswa meningkat.

Lokasi dan Subjek penelitian ini adalah siswa kelas V SDN Widorokandang Kecamatan Pati Kabupaten Pati semester 1 tahun 2018/2019. Jumlah siswa yang terdapat pada kelas $\mathrm{V}$ yaitu sejumlah 20 siswa terdiri dari siswa perempuan 6 dan siswa laki-laki 14 . Dasar pemilihan subjek penelitian berdasarkan pada hasil observasi dan wawancara dengan siswa dan guru kelas V. Kelas V SDN Widorokandang dipilih sebagai subjek peneliti dikarenakan atas studi pendahuluan dengan guru kelas serta dengan dosen pembimbing skripsi. Karakteristik pada siswa kelas V SDN Widorokandang adalah cederung pasif dan merasa kurang senang dan tertarik pada pembelajaran sehingga nilainya cenderung kurang.

PTK ini dilaksanakan dalam bentuk siklus yang terdiri dari empat tahapan sesuai dengan model Kurt Lewin, yaitu: a) perencanaan (planing), b) tindakan (acting), c) pengamatan (observing), dan d) refleksi (reflecting). Tindakan yang peneliti berikan dalam proses pembelajaran di SDN Widorokandang yaitu dengan menerapkan media utangklek pada muatan IPS dan Bahasa Indonesia.

Adapun tahap perencanaan yang akan peneliti lakukan adalah sebagai berikut: (1) menyusun silabus dan Rencana Pelaksanaan Pembelajaran (RPP), (2) media utangklek, (3) menyusun kisi-kisi soal evaluasi, (4) menyusun lembar soal tes akhir siklus, (5) menyusun pedoman penskoran dan kunci jawaban, (6) menyusun pedoman observasi aspek keterampilan, (7) menyusun lembar observasi aspek keterampilan.

Tahap pelaksanaan merupakan tindakan yang dilakukan peneliti selama 2 siklus dengan mengacu pada tahap perencanaan yang telah dibuat sebelumnya. Pelaksanaan tindakan berupa penerapan media utangklek yang dilakukan selama 2 siklus atau 4 kali pertemuan. Bersamaan dengan tahap pelaksanaan, juga terdapat pengamatan yang dilakukan 1 observer yaitu teman sejawat peneliti. Dalam tahap ini, teman sejawat berusaha mengamati seluruh kegiatan yang 
terjadi saat pembelajaran berlangsung, yaitu mengamati keterampilan siswa.

Tahap yang terakhir yaitu refleksi, pada tahap ini bertujuan untuk mengetahui apakah pada pertemuan atau siklus sebelumnya berhasil atau tidak. Jika dari hasil refleksi masih ada permasalahan, maka dilakukan proses perencanaan ulang,tindakan ulang, dan pengamatan ulang harus dilakukan sampai dinyatakan berhasil.

Penelitian ini memiliki dua jenis data yang akan peneliti gunakan untuk memaparkan hasil penelitian yang telah dilaksanakan yaitu data kualitatif dan data kuantitatif. Data kualitatif diperoleh dari hasil observasi dengan cara menggunakan lembar pengamatan aspek keterampilan, wawancara dengan guru mengenai proses pembelajaran khususnya muatan IPS dan Bahasa Indonesia serta dokumentasi pembelajaran. Sedangkan data kuantitatif diperoleh dari keterampilan siswa pada saat pembelajaran berlangsung, hasil belajar siswa yang diambil pada saat pemberian tes di akhir siklus pada muatan IPS dan Bahasa Indonesia. Setiap siklus diperoleh data atau skor setiap siswa dilihat dari nilai peningkatan hasil belajar yang di capai.

Peneliti memperoleh sumber data dari primer siswa, guru, dan dokumentasi. Pada siswa yaitu peneliti peroleh dari hasil wawancara dengan siswa kelas V SDN Widorokandang, observasi hasil belajar aspek keterampilan, materi pembelajaran, dan dokumentasi yang peneliti dapatkan selama proses pelaksanaan siklus I dan siklus II baik berupa penskoran maupun deskriptif. Sedangkan dari guru peneliti peroleh dari lembar observasi wawancara mengenai pembelajaran di kelas. Dari dokumentasi berupa lembar pengamatan siswa dalam proses pembelajaran dan foto untuk dijadikan dokumentasi untuk menggambarkan jalannya pelaksanaan pembelajaran. Sedangkan pada data sekunder berupa jurnal penelitian yang relevan, referensi buku-buku, lembar pengamatan siswa, foto, daftar siswa kelas $\mathrm{V}$ SDN Widorokandang, daftar nama kelompok siswa kelas V, nilai ulangan harian yang telah dilaksanakan siswa kelas V SDN Widorokandang.

Metode pengumpulan data penelitian, peneliti menggunakan teknik tes dan non tes. Tes yang digunakan oleh peneliti yaitu berbentuk uraian dilaksanakan pada akhir siklus. Tes digunakan untuk mengetahui hasil belajar siswa melalui penerapan media utangklek pada subtema Keseimbangan Ekosistem mutan IPS dan Bahasa Indonesia. sedangkan teknik non tes yang peneliti gunakan yaitu wawancara, observasi, dan dokumentasi.

Dalam penelitian ini, analisis data kuantitatif dianalisis secara deskriptif kuantitatif. Pada penilaian hasil belajar siswa berupa angka dengan menggunakan skor dari masing-masing nomor soal yaitu 1-4 sesuai dengan pedoman penilaian yang telah dibuat oleh peneliti. Peneliti akan menggunakan 8 butir soal uraian yang terdiri dari 4 muatan IPS dan 4 muatan Bahasa Indonesia pada evaluasi di akhir siklus I dan akhir siklus II sehingga skor yang tertinggi pada masing-masing muatan yaitu dari hasil skor maksimal dikalikan dengan jumlah butir soal. Adapun cara penentuan nilai siswa secara individu dapat menggunakan rumus:

$$
\text { Nilai Akhir }=\frac{\text { SkorFerolshan }}{\text { SkorMaksmal }} \times 100
$$

Setelah memperoleh hasil perhitungan, kemudian dikonsultasikan pada tabel ketuntasan di SDN Widorokandang dengan kriteria sebagai berikut:

Tabel 1. KKM IPS Kelas V SDN Widorokandang

\begin{tabular}{|c|c|}
\hline $\begin{array}{c}\text { Kriteria Ketuntasan } \\
\text { IPS }\end{array}$ & Kualifikasi \\
\hline$\geq 70$ & Tuntas \\
\hline$<70$ & Tidak Tuntas \\
\hline
\end{tabular}

Tabel 2. KKM Bahasa Indonesia Kelas V SDN Widorokandang

\begin{tabular}{|c|c|}
\hline $\begin{array}{c}\text { Kriteria Ketuntasan } \\
\text { Bahasa Indonesia }\end{array}$ & Kualifikasi \\
\hline$\geq 70$ & Tuntas \\
\hline$<70$ & Tidak Tuntas \\
\hline
\end{tabular}

Peneliti menghitung persentase ketuntasan belajar secara klasikal. Kriteria ketuntasan belajar klasikal dinyatakan tercapai apabila hasil perhitungan ketuntasan belajar siswa $\geq 75 \%$. Perhitungan ketuntasan hasil belajar siswa secara klasikal dihitung dengan rumus sebagai berikut:

\section{$\frac{\sum \text { siswayangtwintasbelajar }}{\sum \text { siswa }} \times 100 \%$}

Data kualitatif digunakan untuk mendukung data kuantitatif. Pada penelitian ini data kualitatif didapatkan dari hasil wawancara, 
observasi penilaian aspek keterampilan dan dokumentasi dalam pembelajaran subtema Keseimbangan Ekosistem muatan IPS dan Bahasa Indonesia dengan menerapkan utangklek. Analisis data kualitatif menggunakan analisis deskriptif.

Indikator keberhasilan dalam penelitian ini adalah hasil belajar pada muatan IPS dan Bahasa Indonesia subtema Keseimbangan Ekosistem siswa kelas V SD N Widorokandang dengan penerapan media utangklek dinyatakan meningkat apabila nilai klasikal mencapai 75\%dengan ketentuan sebagai berikut: (a) Pada aspek pengetahuan, nilai siswa mencapai KKM muatan IPS 70 dan KKM muatan Bahasa Indonesia adalah 70 sesuai dengan KKM di SD $\mathrm{N}$ Widorokandang. (b) Pada aspek keterampilan muatan IPS, nilai siswa mencapai 62,5 dengan kualifikasi baik. Pada muatan Bahasa Indonesia, nilai siswa mencapai 58,33 dengan kualifikasi baik.

\section{HASIL DAN PEMBAHASAN}

Hasil penelitian ini diuraikan dalam 4 tahapan sesuai dengan yang sudah direncanakan, yaitu perencanaan, tindakan, observasi, dan refleksi. Pada siklus I peneliti melakukan perencanaan yaitu: (1) menyusun silabus pembelajaran, (2) menyusun Rencana Pelaksanaan Pembelajaran (RPP), menyusun kisi-kisi soal evaluasi siklus I, (4) menyusun soal evaluasi siklus I, (5) menyusun kunci jawaban dan pedoman penskoran soal evaluasi siklus I, (6) menyusun lembar pengamatan keterampilan siswa, (7) media pembelajaran utangklek.

Siklus I dilaksanakan dalam 2 kali pertemuan. Pertemuan 1 dilaksanakan pada hari Kamis 15 November 2018 dan pertemuan kedua dilaksanakan pada hari Jum'at 16 November 2018 dengan alokasi waktu setiap pertemuan 6x35 menit. Tahap pelaksanaan dan pengamatan dilakukan dalam waktu yang sama. Pengamatan terhadap keterampilan siswa dilakukan oleh teman sejawat peneliti.

Hasil belajar aspek pengetahuan siswa pada tema 5 ekosistem subtema kesimbangan ekosistem pada muatan IPS pada siklus I memperoleh rata-rata 67,91 . Terdapat 12 siswa yang tuntas dan 8 siswa yang tidak tuntas dengan ketuntasan klasikal sebesar $60 \%$. Sedangkan pada muatan Bahasa Indonesia pada siklus I memperoleh rata-rata 75 . Terdapat 13 siswa yang tuntas dan 7 siswa yang tidak tuntas dengan ketuntasan klasikal sebesar $65 \%$.
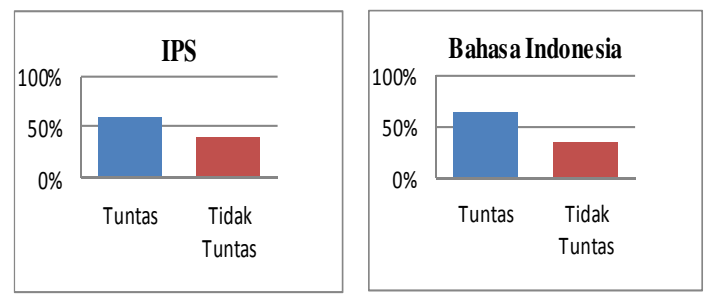

Gambar 1 Diagram Ketuntasan Klasikal Siklus I Muatan IPS dan Bahasa Indonesia

Pelaksanaan pembelajaran siklus I dengan penerapan media utangklek sudah berlangsung dengan baik. Namun, masih terdapat beberapa kekurangan atau permasalahan pada siklus I selama pembelajaran berlangsung. Berdasarkan pada hasil penelitian siklus I ditemukan beberapa permasalahan yaitu (1) masih terdapat beberapa siswa yang ramai sendiri saat memainkan utangklek, (2) terdapat beberapa siswa yang masih ragu dan tidak berani dalam mengemukakan jawabannya. Kedua permasalahan tersebut dikarenakan kurangnya motivasi dalam diri siswa dan kurang adanya peran guru. Selaras dengan pendapat Pratiwi, dkk (2018) bahwa siswa sejak dini harus dimotivasi untuk melakukan suatu kegiatan secara bersama.

Berdasarkan hasil refleksi pada siklus I, selanjutnya dilakukan perbaikan pada siklus II. Rata-rata nilai muatan IPS yang diperoleh siswa pada siklus II yaitu 80,63 . Siswa yang tuntas sebanyak 16 siswa dan siswa yang tuntas sebanyak 4 siswa dari jumlah 20 siswa kelas V SDN Widorokandang. Sehingga ketuntasan belajar klasikal sebesar $80 \%$ dengan kriteria baik. Nilai rata-rata muatan Bahasa Indonesia yang diperoleh siswa yaitu 81,25. Siswa yang tuntas sebanyak 16 siswa dan siswa yang tidak tuntas sebanyak 4 siswa dari jumlah 20 siswa, sehingga ketuntasan belajar klasikal sebesar $80 \%$ dengan kriteria baik. Berikut merupakan diagram ketuntasan klasikal pada siklus II.
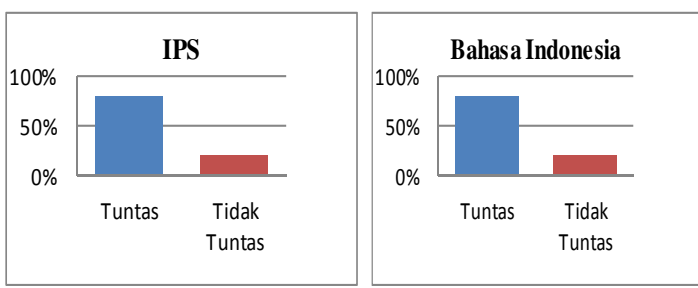

Gambar 2 Diagram Ketuntasan Klasikal Siklus II Muatan IPS dan Bahasa Indonesia

Dalam siklus II ini sebagian besar siswa dapat mengerjakan soal evaluasi tingkatan C1,C2,C3, dan C4. Sedangkan pada tingkatan 
C5 dan C6 siswa sudah dapat mengerjakannya dengan baik, namun masih ada beberapa siswa yang masih mengalami kesulitan dalam memahami dan mengerjakan soal.

Peningkatan hasil belajar siswa dikarenakan penerapan media utangklek dalam pembelajaran. Media pembelajaran berupa permainan tradisional yang menarik dan menyenangkan membantu guru dalam transformasi informasi kepada siswa dengan cara yang menyenangkan. Hal tersebut sesuai dengan pendapat Ardianti, dkk (2019) bahwa pembelajaran tentang budaya lokal yang dikemas dengan permainan yang menyenangkan akan membantu siswa dalam mencapai tujuan pembelajaran. Pencapaian tujuan pembelajaran berdampak pada peningkatan hasil belajar siswa.

Hasil observasi aspek keterampilan siklus I pada muatan IPS memperoleh nilai rata-rata 62,82 dengan persentase keberhasilan siswa sebesar $65 \%$, sedangkan pada muatan Bahasa Indonesia memperoleh nilai rata-rata 61,25 dengan persentase keberhasilan siswa sebesar 55\%. Berikut merupakan diagram mengenai keterampilan siswa dengan menerapkan media utangklek pada siklus I.

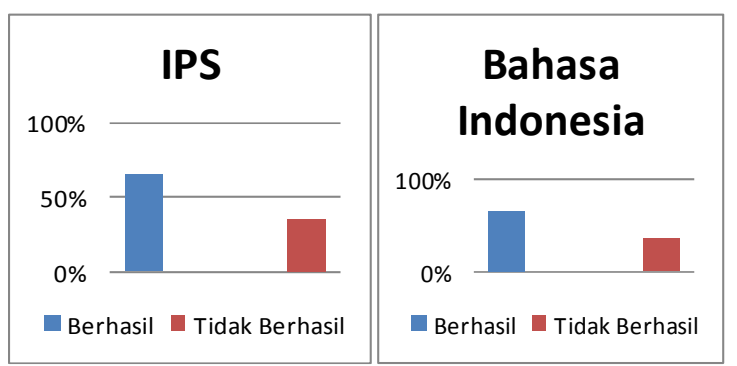

Gambar 3. Diagram Tingkat Keberhasilan Hasil Belajar Aspek Keterampilan Siklus I Muatan IPS dan Bahasa Indonesia

Berdasarkan pada hasil penelitian siklus I ditemukan beberapa permasalahan yaitu (1) masih terdapat banyak siswa yang masih belum sepenuhnya memiliki keseriusan dalam menerapkan media utangklek., (2) sebagian besar siswa sudah serius dalam melaksanakan permainan utangklek, akan tetapi siswa masih terdapat yang tidak tertib dan suka mengganggu temannya yang sedang giliran bermain, (3) masih terdapat beberapa siswa yang asyik mengganggu temannya ketika sedang diskusi. Ketiga permasalahan tersebut dikarenakan belum memiliki keseriusan dalam memainkan utangklek. Berdasarkan hasil siklus I diketahui bahwa indikator keberhasilan belum tercapai, sehingga peneliti ingin melanjutkan pada siklus II. Hasil observasi pada siklus II disajikan dalam gambar berikut ini.

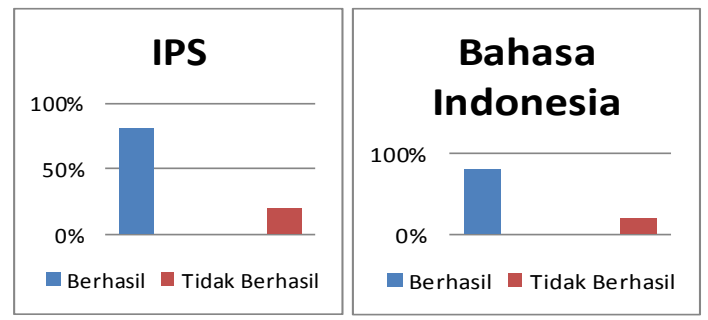

Gambar4 Diagram Tingkat Keberhasilan Hasil Belajar Aspek Keterampilan Siklus II Muatan IPS dan Bahasa Indonesia

Setelah perbaikan pada siklus II dilaksanakan, hasil observasi apek keterampilan pada muatan IPS dan Bahsa Indonesia mengalami peningkatan. Pada muatan IPS siswa memperoleh nilai rata-rata 71,40 dengan persentase keberhasilan siswa sebesar 80\%, sedangkan pada aspek keterampilan siswa siklus II muatan Bahasa Indonesia memperoleh nilai rata-rata 68,13 dengan persentase keberhasilan siswa sebesar $80 \%$. Dalam siklus II ini guru memberikan arahan dan motivasi agar siswa lebih aktif dalam pembelajaran dengan menerapkan media utangklek. Pratiwi dan Kuryanto (2019) berpendapat bahwa penerapan permainan tradisional dalam pembelajaran berkorelasi positif dengan keterampilan dan karakter kerjasama siswa. Kebutuhan utama siswa merupakan informasi konkret terhadap peristiwa sosial yang dialami dalam kehidupan sosial bermasyarakat (Fajrie dan Imaniar, 2017). Pendidikan karkater yang diperoleh siswa pada penelitian ini antara lain: karekter tanggung jawab, disiplin, kerjasama, kerja keras, peduli sosial. Berdasarkan pada hasil tersebut, peneliti dapat menyimpulkan bahwa indikator keberhasilan telah tercapai.

Berdasarkan pada analisis data dapat disimpulkan bahwa media utangklek dapat meningkatkan hasil belajar siswa. Hasil penelitian ini menunjukkan bahwa terdapat peningkatan pada aspek pengetahuan dan keterampilan siswa di setiap siklus pada siswa kelas V SD Widorokandang.

\section{SIMPULAN}

Berdasarkan pada hasil penelitian tindakan kelas dengan menerapkan media utangklek pada tema 5 subtema keseimbangan ekosistem kelas V SD N Widorokandang mengalami peningkatan. Hal tersebut dapat dibuktikan dengan meningkatkanya hasil belajar siswa pada aspek pengetahuan dan 
keterampilan siswa. Pada muatan IPS pada siklus I memperoleh $60 \%$ kemudian pada siklus II meningkat lagi menjadi $80 \%$. Pada muatan Bahasa Indonesia siklus I memperoleh $65 \%$ pada siklus I kemudian pada siklus II meningkat lagi menjadi $80 \%$. Sehingga hasil belajar aspek pengetahuan pada muatan IPS dan Bahasa Indonesia subtema Keseimbangan Ekosistem siswa kelas V SD N Widorokandang dengan penerapan media utangklek dinyatakan meningkat dan telah mencapai nilai klasikal $75 \%$.

Sedangkan pada aspek keterampilan siswa siklus I muatan IPS siswa kelas V SD N Widorokandang memperoleh persentase keberhasilan siswa sebesar 65\%. siklus II meningkat dan memperoleh persentase keberhasilan siswa sebesar $80 \%$, sehingga ratarata hasil belajar aspek keterampilan siswa muatan IPS sudah mencapai indikator yang ditetapkan yaitu $75 \%$. Sedangkan pada aspek keterampilan siswa siklus I muatan Bahasa Indonesia memperoleh persentase keberhasilan siswa sebesar 55\%. Di siklus II meningkat dan memperoleh persentase keberhasilan siswa sebesar $80 \%$. sehingga rata-rata hasil belajar aspek keterampilan siswa muatan IPS sudah mencapai indikator yang ditetapkan yaitu $75 \%$.

Berdasarkan simpulan di atas, peneliti mengajukanbeberapa saran,disarankan siswa lebih bisa serius dan menjaga perilaku terhadap siswa yang lain dan peneliti. Guru sebaiknya melakukan pembelajaran yang menuntut peran aktif siswa melalui model dan media yang menarik siswa. Sekolah sebaiknya memberikan kebijakan penyediaan sarana dan prasarana yang dapat mendukung proses pembelajaran dengan baik, khususnya pada penyediaan media pembelajaran yang sangat penting bagi guru dan siswa.

\section{DAFTAR PUSTAKA}

Ardianti, SD. 2015. Pengaruh Modul Tematik Inquiry-Discovery Terhadap Hasil Belajar Siswa Materi Metabolisme Pembentuk Bioenergi. Refleksi Edukatika: Jurnal Ilmiah Kependidikan, 5 (2): 1-6.

Ardianti SD, Wanabuliandari S, dan Kanzunnudin, Moh. 2019. Implementasi Pembelajaran Berbasis EtnoEdutainmnet Untuk Meningkatkan Karakter Cinta Tanah Air Siswa Sekolah Dasar. Refleksi Edukatika: Jurnal Ilmiah Kependidikan, 9(2): 204 209.
Hakim, BR dan Haryudo SI. 2014. Pengembangan Media Pembelajaran Interaktif Animasi Flash pada Standar Komptensi Memsang Instalasi Penerangan Listrik Bangunan Sederhana di SMK Walisongo 2 Gempol. Jurnal Pendidikan Teknik Elektro, 3 (1): 15-21.

Hapidin dan Yenina. 2016. Pengembangan Model Permainan Tradisional dalam Membangun Karakter Anak Usia Dini. Jurnal Pendidikan Usia Dini, 10 (2): 201-212.

Ismaya, Erik Aditia., dan Santoso. 2019. Tradisi Dandangan Sebagai Kajian Pembelajaran Dalam Mendukung Pencapaian Visi Universitas Kebudayaan (Studi pada Mata Kuliah Konsep Ilmu Pengetahuan Sosial). Refleksi Edukatika: Jurnal Ilmiah Kependidikan, 10(1): 128-137.

Mardayani, Komang Trisna, Dkk. 2016. Penerapan Permainan Tradisional Engklek Untuk Meningkatkan Kemampuan Motorik Kasar Kelompok B di PAUD Wudhya Laksmi. e-Journal Pendidikan Anak Usia Dini Universitas Pendidikan Ganesha, 4 (2).

Mas'udah, Nur Hanum, Nurul Aini. 2018. Penerapan Model Picture And Picture untuk Meningkatkan Hasil Belajar Siswa pada Mata Pelajaran Kelas III SDN Balonggabus Candi. Journal of Indonesian Education, 1(1).

Nurbaiti, Hilmi. 2018. Penerapan Model Pembelajaran Mnemonik untuk Meningkatkan Hasil Belajar Siswa Kelas VIII SMP-AL HIDAYAH Medan pada Mata Pelajaran PPKn Tahun Pembelajaran 2017/2018. Skripsi. Medan: Universitas Negeri Medan.

Fajrie, Nur dan Purbasari, Imaniar. 2017. Pembelajaran Tematik SD Bermuatan IPS dengan media gambar sederhana. Prosiding Seminar Nasional Pendidikan PGSD UMS \& HDPGSDI Wilayah Jawa.

Oktavianti, Ika, Yuni Ratnasari. 2017. Permainan Monopoli Engklek Jelajah Budaya Pati untuk Pembelajaran Tematik. Prosiding Seminar Nasional 
Frandika Fajar Juliarto, Ika Oktavianti, dan Imaniar Purbasari

IMPLEMENTASI MEDIA UTANGKLEK TERHADAP PENINGKATAN HASIL BELAJAR ...

WASIS: Jurnal Ilmiah Pendidikan. Volume 1, Nomor 1, Mei 2020, hlm. 36-43

Pembelajaran Bahasa dan Sastra Indonesia Berbasis Kearifan Lokal dalam Pembentukan Karakter Bangsa, 18 Mei 2017, 63-68.

Pratiwi, Ika Ari., Ardianti, Sekar Dwi., dan Kanzunnudin, Moh. 2018. Peningkatan Kemampuan Kerjasama Melalui Model Project Based Learning (PjBL) Berbantuan Metode Edutainment Pada Mata Pelajaran Ilmu Pengetahuan Sosial. Refleksi Edukatika: Jurnal Ilmiah Kependidikan, 8(2): 177-182.
Pratiwi, Ika Ari., dan Kuryanto MS. 2019. Correlation Betengan Tradisional Games on Locomotor Movement and Characters. Refleksi Edukatika: Jurnal Ilmiah Kependidikan, 10(1): 71-76.

Sadiman, Aris S, dkk. 2014. Media Pendidikan: Pengertian, Pengembangan dan Pemanfaatannya. Jakarta: Rajawali Pers

Sjukur, Sulihin B. 2012. Pengaruh Blended Learning terhadap Motivasi Belajar dan Hasil Belajar Siswa Tingkat SMK. Jurnal Pendidikan Vokasi, 2 (2).

Uno, Hamzah, Lamattenggo, Nina dan Satria. 2011. Menjadi Peneliti PTK yang Profesional. Jakarta: Bumi Aksara 